\title{
Artefatos e práticas sociais em torno das refeições \\ (São Paulo, séculos XVIII e XIX)
}

\author{
Artifacts and Social Practices Around Meals \\ (São Paulo, $18^{\text {th }}$ and $19^{\text {th }}$ Centuries) \\ Maria Aparecida de Menezes Borrego \\ Museu Paulista, Universidade de São Paulo \\ Rua Brigadeiro Jordão, 149 \\ Ipiranga , São Paulo, SP, 04.210-000, Brasil \\ maborrego@usp.br
}

Resumo Em 1923, ingressava no Museu Paulista, por vontade testamentária de D. Francisca Miquelina de Paula de Souza Queiroz, um conjunto de duas cadeiras, canapé e mesa que havia pertencido a seu avô, o Brigadeiro Luis Antonio de Souza Queiroz, uma das maiores fortunas da primeira metade do século XIX paulista, falecido em 1819.Seus atributos físicos são testemunhos das transformações socioeconômicas e incitam à reflexão sobre o significado da posse de objetos, as relações pessoais por eles mediadas e o papel conformador de práticas sociais desempenhado pelos artefatos. A partir do estudo desses móveis e dos bens descritos em inventários de habitantes da cidade de São Paulo, o artigo analisa a dimensão material da vida social, nos séculos XVIII e inícios do XIX, focalizando as práticas sociais em torno das refeições no espaço doméstico, num contexto marcado pela gradual interiorização das sociabilidades.

Palavras-Chave alimentação, materialidade, espaço doméstico

Recebido: 08 de agosto de 2015 | Aprovado: 25 de outubro de 2015

http://dx.doi.org/10.1590/0104-87752016000100006

Varia Historia, Belo Horizonte, vol. 32, n. 58, p. 101-137, jan/abr 2016 
Abstract In 1923, a set of two chairs, a settee and a sofa table were donated to Museu Paulista, as a clause of D. Francisca Miquelina de Paula de Souza Queiroz's family will. These pieces of furniture originally belonged to his grandfather, Brigadier Luis Antonio de Souza Queiroz, one of the wealthiest men in the first half of the $19^{\text {th }}$ century in São Paulo, deceased in 1819. Their physical attributes are testimonies of the social and economic transformations and stimulate to reflect on the meaning of possession of objects, the personal relationships mediated by them and the shaping role of social practices played by artifacts. Based on the study of these pieces of furniture and goods described in inhabitants' wills of São Paulo, the article analyzes the material dimension of social life, in the eighteenth and early nineteenth centuries, focusing on the social practices around meals in the domestic environment in a context marked by the gradual internalization of sociability.

KEYWORDs food, materiality, domestic space

\section{INTRODUÇÃO}

Em 1819, morreu em São Paulo o Brigadeiro Luis Antonio de Souza Queiroz, abastado homem de negócios e proprietário de terras. Cerca de 20 anos depois, foi lavrado o inventário da viúva, D. Genebra de Barros Leite. A partir daí, uma das maiores fortunas paulistas da primeira metade do século XIX seria sucessivamente partilhada entre os descendentes do casal, chegando às mãos da neta, D. Francisca Miquelina de Paula de Souza Queiroz, bens integrantes da opulenta residência do brigadeiro, localizada no centro da cidade de São Paulo.

Em 1923, quando da morte de D. Francisca Miquelina, por vontade testamentária, foram doadas ao Museu Paulista algumas peças de mobiliário que faziam parte da referida residência, entre as quais um conjunto de 2 cadeiras, sofá e mesa. ${ }^{1}$ Serão esses exemplares os pontos de

1 O acervo geral do Museu Paulista teve como um de seus núcleos fundadores a coleção de objetos reunida pelo coronel Joaquim Sertório em sua residência, da qual constavam espécimes de 
partida para a análise de práticas sociais em torno das refeições vivenciadas pelos habitantes da cidade de São Paulo em fins do século XVIII e inícios do XIX, contexto marcado, no âmbito das elites, pela gradual interiorização das sociabilidades no espaço doméstico.

Além de considerar os atributos físicos dos móveis como testemunhos das transformações socioeconômicas, suas qualidades materiais incitam a pensar sobre as diferentes formas de interação entre corpos e artefatos numa determinada conjuntura e o decorrente papel dos artefatos - quando em uso pelos indivíduos - como mediadores de relações humanas e conformadores de práticas sociais (Meneses, 1983; 2005).

Nesta perspectiva analítica, merecem destaque os estudos de Mimi Hellman, Dena Goodman e Carolyn Sargentson, que focalizaram as formas pelas quais a persona da elite social francesa foi produzida através das dinâmicas formais e significados culturais do uso do mobiliário no contexto doméstico francês do Antigo Regime (Hellman, 1999; Goodman, 2003; Sargentson, 2006); ${ }^{2}$ os trabalhos de Amanda Vickery e John Styles sobre a conformação de identidades sociais e de gênero a partir da posse e uso de artefatos no universo inglês setecentista (Vickery, 2009; Styles, 2006) e os de Vânia Carneiro de Carvalho sobre a incorporação de formas de distinção social e de gênero por meio do emprego de objetos domésticos em São Paulo em inícios do século XX (Carvalho, $2003 ; 2008 ; 2011)$.

Se, por um lado, a casa mostra-se altamente eficaz na reprodução social uma vez que corpos e objetos interagem de maneira inconsciente e automatizada, também é neste ambiente que as mudanças sociais são engendradas, não como meros reflexos do mundo exterior, mas como parte ativa na indução dessas alterações (Carvalho, 2008, p.216).

história natural e peças de interesse etnográfico e histórico, entre as quais móveis. Em 1890, a coleção foi doada ao Governo do Estado de São Paulo, ao ser criado o Museu do Estado, logo rebatizado de Museu Paulista, que passou a funcionar oficialmente no local onde se encontra, no bairro do Ipiranga, em 1895.

2 Ver ainda os ensaios destas autoras em GOODMAN; NORBERG, 2007. 
O levantamento das fontes e a leitura da bibliografia acerca da temática da materialidade da alimentação no cotidiano das residências coloniais sugeriram que as práticas sociais em torno das refeições estavam associadas ao ato de sentar que, em realidade, condicionava a forma como se daria o comer e o beber. Ainda que, à primeira vista, pareça natural porque relacionado à postura de descanso e conforto, tal atitude corporal e os afazeres a ela relacionados exigem aprendizagem e se transformam ao longo do tempo de acordo com os móveis utilizados e com os preceitos vigentes - mesmo que tácitos e costumeiros.

Fernanda de Castro Freire considera as cadeiras as peças mais representativas e definidoras do seu tempo, pois, para além da função básica, informam sobre as relações humanas, já que continuamente foram usadas como símbolo de hierarquização e estratificação social (Freire, 2001, p.10). Igualmente Nuno Luis Madureira considera que a cadeira "é o indicador fiável das mudanças, o melhor repositório de marcas significativas de um estilo, o elemento de pesquisa através do qual a cronologia se desvenda" (Madureira, 1992, p.164).

Tendo em vista tais considerações, este artigo está dividido em 3 partes. Na primeira parte, contempla-se brevemente o desenvolvimento social e urbano da cidade de São Paulo em fins do período colonial; na segunda, tomando os móveis de assento como plataformas privilegiadas de observação da realidade doméstica, reflete-se sobre as práticas alimentares no decorrer do século XVIII e inícios do XIX, articuladas ao processo de interiorização das sociabilidades, que corresponde ao contexto de origem dos móveis do Brigadeiro, certamente empregados em momentos de refeições; na terceira, mostra-se como o estudo conjugado das peças coloniais remanescentes no Museu com os artefatos mencionados em inventários favorece tanto a compreensão das dinâmicas sociais de determinado período, como a dos próprios objetos musealizados, inteligíveis a partir de sua utilização no circuito econômico e familiar. 


\section{O Centro da cidade de São Paulo EM INÍCIOS DO OITOCENTOS}

De acordo como Relatório Anual de Atividades do Museu Paulista, de 1923, o conjunto de mobília doado à instituição pertencera ao Brigadeiro Luis Antonio ${ }^{3}$ e, portanto, devia ter ocupado alguma das salas do sobrado do qual ele era proprietário, situado na esquina das ruas do Ouvidor e de São Bento, dois importantes logradouros da cidade de São Paulo em inícios do século XIX, cujo centro vinha se desenvolvendo continuamente ao longo dos setecentos, capitaneado pelos portugueses ligados às atividades mercantis que decidiram aí fixar residência (Borrego, 2010a).

As ruas do Ouvidor e de São Bento estavam localizadas na Sé, na área "expandida" do Triângulo, formado pelas duas principais ruas da cidade - Direita e São Bento - que se cortavam em ângulo reto, no cruzamento denominado Quatro Cantos, e pela rua do Rosário. Nessa configuração espacial, os destacados edifícios religiosos de São Bento, São Francisco e Carmo ocupavam os vértices do chamado "Triângulo" (Toledo, 2004).

De acordo com os dados da décima urbana de 1809, a estreita colina delimitada pelos rios Tamanduateí e Anhangabaú, era composta por cerca de 34 ruas, e 10 dos 13 imóveis mais caros tinham uso comercial ou misto, o que revela o papel significativo do grupo mercantil como produtor de boa parte do tecido urbano de São Paulo. O Brigadeiro Luis Antonio de Souza, ainda coronel em 1809, por exemplo, já se destacava em terceiro lugar na listagem dos maiores proprietários urbanos leigos da cidade de São Paulo, sendo possuidor de 7 imóveis (Bueno, 2005).

Tal quadro corresponde ao contexto da transferência da família real para o Brasil. A proximidade da Corte e a experiência pregressa dos paulistas com a venda de tropas, alimentos e mercadorias abriram renovados horizontes ao comércio que já se desenvolvia em São Paulo, provocando impactos na área central da capital paulista cada vez mais

3 Relatório anual referente ao ano de 1923. Revista do Museu Paulista, 1926, vol. 14, p.805. 
marcada pelo adensamento populacional e pela diversificação profissional de seus habitantes (Araújo, 2004; 2006).

No caso de vários homens de negócios, portugueses de origem como o Brigadeiro Luis Antonio, ${ }^{4}$ ou nascidos em solo colonial - filhos, genros e netos de comerciantes estabelecidos em São Paulo ao longo dos setecentos -, tal diversificação profissional significou a conjugação de lides mercantis com agropecuárias, relacionadas à produção e exportação de açúcar. Esta última atividade vinha sendo implantada na capitania de São Paulo desde a chegada do Morgado de Mateus, em 1765, no âmbito da política pombalina de estímulo à produção agrícola e à dinamização do comércio. $\mathrm{O}$ fato de se tornarem proprietários de engenho não significou, contudo, o abandono das modalidades mercantis que haviam sido o cerne do acúmulo de fortunas de seus antepassados - sobretudo o comércio de fazenda seca e de escravos (Borrego, 2010b; Médicci, 2010; Mattos, 2015). Ademais, vários comerciantes/ senhores de engenho continuaram a viver nos sobrados da área central de São Paulo, como o Brigadeiro Luis Antonio que mantinha no andar térreo de sua residência uma loja de fazenda seca extremamente sortida.

A importância da capital e do grupo mercantil nela residente no conjunto da capitania/província de São Paulo foi atestado pelas pioneiras pesquisas Maria Luiza Marcílio $(1974 ; 2000)$ e as mais recentes de Francisco Vidal Luna e Herbert Klein. Ao estudarem as características da população a partir dos censos e das listas nominativas dos habitantes, os estudiosos concluíram que, nos anos de 1765/1768, a população residente na região da capital totalizava 28.307 indivíduos, cifra reiteradamente aumentada nos decênios posteriores. Em 1777, a região da capital contava com 41.369 habitantes, correspondendo a quase um terço da população total da capitania; em 1804, contabilizava 55.453 moradores de um total de 191.288 espalhados pela província, e, por fim, em 1829, somava 61.957 habitantes, frente ao total de 269.621 indivíduos (Luna; Klein, 2005).

4 Luis Antonio de Souza Queiroz nasceu em Amarante, em 1755. Arquivo da Cúria Metropolitana de São Paulo. Dispensas e processos matrimoniais, 6- 51 - 217. 1797. 
Neste último período, a cidade de São Paulo já rivalizava em termos populacionais com as regiões do Vale do Paraíba, Oeste Paulista e Caminho do Sul, em razão do desenvolvimento das atividades agropecuárias. Mesmo assim, a cidade desfrutava de uma posição de destaque no conjunto, haja vista que nenhuma outra vila isolada poderia ser a ela comparada.

Se nessa conjuntura de inícios do século XIX, Luis Antonio de Souza gozava de proeminência social, econômica e política no cenário paulista, não se pode esquecer que, no Brasil, iniciou suas atividades como tropeiro entre a capitania de São Paulo e Cuiabá, como tantos outros conterrâneos que vieram ainda moços para tentar a sorte no centro-sul da América Portuguesa (Borrego, 2010a). Em 1786, recebeu sua primeira patente de tenente agregado à Companhia de cavalaria da vila de Itu; em 1792 foi elevado a capitão e, 4 anos depois, a tenente-coronel (Marins, 2005).

A fortuna que vinha amealhando somada às patentes militares alcançadas lhe facultou desposar, em 1797, Genebra de Barros Leite, membro de uma das mais importantes famílias de Itu, vila localizada no quadrilátero do açúcar. Por sua vez, tal união conjugal lhe garantiu no ano seguinte a elevação ao posto de coronel e a obtenção de sua primeira sesmaria também na região.

Ainda que em seu inventário, cujo monte mor correspondia a cerca de 300 contos de réis, constassem mais de quinze propriedades rurais espalhadas pelo interior de São Paulo, o casal e filhos residiam no já mencionado sobrado no centro da capital paulista, que se destacava em face das moradas térreas e dos "falsos" sobrados de taipa de pilão ainda predominantes no cenário urbano no alvorecer dos oitocentos (Lemos, 1999).

Para além dos 2 andares, a residência, construída em meados de 1810, contava com "quatro lanços, com seu quintal murado, e com suas lojas e muito cômodo por baixo, e uma cocheira" e foi avaliada no inventário em $4: 400 \$ 000 .^{5}$

5 Arquivo do Tribunal de Justiça do Estado de São Paulo. Luis Antonio de Souza Queiroz: Inventários do $1^{\circ}$ cartório de família, proc. 513 - 1819. 
Sua imponência é visível no panorama desenhado pelo inglês Charles Landseer, quando esteve na cidade em torno de 1827 (Toledo, 2007). Fotografias de Militão Augusto de Azevedo, realizadas na década de 1860 , permitem igualmente dimensionar a escala expressiva do sobrado, mais de quarenta anos após sua construção, como já chamara a atenção Paulo Cesar Garcez Marins (Marins, 2005).

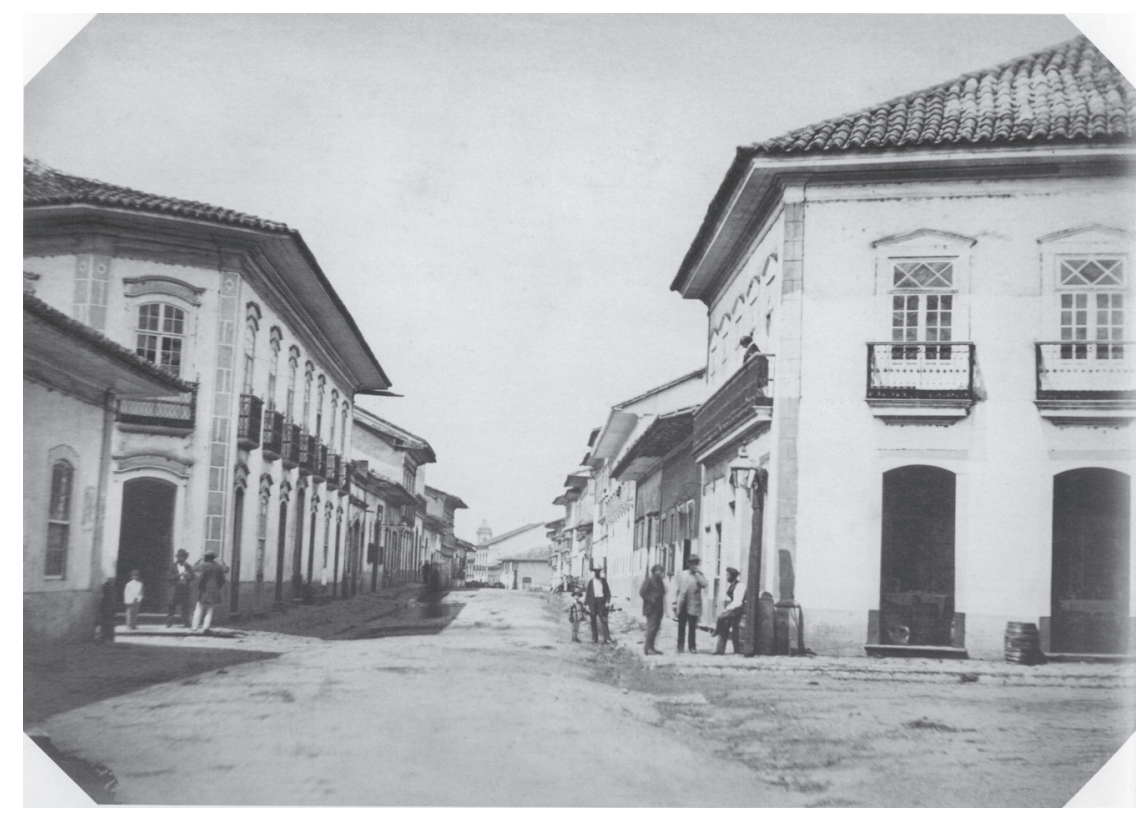

Figura 1 - Rua do Ouvidor esquina com Rua São Bento fotografada por Militão de Azevedo, 1862/63, notando-se à esquerda o casarão originalmente pertencente ao Brigadeiro Luis Antonio. Acervo do Museu Paulista/USP. Reprodução de Hélio Nobre.

Era nele que o Brigadeiro e sua esposa protagonizavam encontros sociais e de negócios, haja vista as 4 salas destinadas à recepção de pessoas alheias ao núcleo familiar mencionadas em seu inventário - sala do canto, do oratório, da espera e da senhora - profusamente recheadas com mobiliário de assento. Houve ainda, por parte dos louvados, o arrolamento de bens numa sala, entre a sala de espera e da senhora, registrada como sala anterior, mas que parece não se confundir com a de espera. 
A individuação da casa em aposentos insere-se no contexto de passagem do século XVIII para o XIX, quando se assistiu à gradativa interiorização das sociabilidades nos ambientes domésticos, principalmente entre os membros da elite (Algranti, 1997). Como comenta Vânia Carvalho, "o dinamismo dos relacionamentos sociais e da vida urbana conjugados à heterogeneidade crescente das elites e aos novos segmentos em ascensão exigiam uma vida social mais intensa, engajando a casa nessa nova rotina de encontros" (2008, p.207).

Fazer da casa um espaço de encontros significava dotá-la de artefatos promotores de distinção social, introduzindo de peças de mobiliário, de alimentação e decorativas que, além das funções originais para as quais eram confeccionadas, passavam a ser dispostas nos aposentos para serem vistas (Madureira, 1992; Suano, 1992; Flexor, 2009; Algranti, 2011).

Nestes novos recintos, cada vez mais adaptados às atividades da vida de salões, disseminadas na Europa a partir da segunda metade do século XVIII, é fundamental assinalar, como o fez Maria de los Angeles Perez Samper para Barcelona setecentista, a existência de um referente alimentar que servia de elemento articulador entre participantes das reuniões promovidas (Perez Samper, 2001). Bebidas como o chocolate, o chá e o café se tornaram, portanto, produtos imprescindíveis nos novos eventos festivos, protagonizando, por exemplo, os rituais do chá tão bem estudados por Tânia de Andrade Lima no Rio de Janeiro oitocentista (Lima, 1997).

Para o contexto paulistano, os resultados de nossas pesquisas indicam que as elites ligadas duplamente ao comércio e à exportação de açúcar - tendo o Brigadeiro Luis Antonio como expoente - não só vivenciaram tais mudanças nas sociabilidades, como as encabeçaram e as difundiram nos interiores domésticos por meio da introdução de artefatos de assento e suporte e/ou da modificação de seus atributos físicos.

Flagrar esse processo na cidade de São Paulo é muito relevante não só no âmbito de atuação dos homens de negócio em face da população local e brasileira, mas mesmo em face das dinâmicas sociais intramuros no cenário europeu que muito se caracterizavam pela ocorrência de espaços restritos e multifuncionais (Olival, 2011; Ramos Palencia, 2010; Roche, 2004; Styles, 2006). 


\section{Práticas alimentares e RelaÇões Sociais NOS INTERIORES DOMÉSTICOS}

Vejamos então como as 2 cadeiras de palhinha, o sofá e a mesa do Brigadeiro pertencentes ao acervo do Museu Paulista, nos ajudam a refletir sobre as mudanças nas práticas alimentares articuladas ao crescimento das relações sociais intramuros.

Entre os vários objetos doados por D. Francisca Miquelina de Paula de Souza Queiroz, o diretor da instituição de 1917 a 1945, Affonso de Taunay, destaca o "valioso legado que seus filhos acabam de cumprir. Figuram nesta deixa uma mobília de sala de jacarandá e palhinha que pertenceu ao avô da doadora, brigadeiro Luiz Antonio de Souza, em seu tempo o homem mais opulento da capitania (...)".6

Os termos empregados pelo diretor já indicam pelo menos 3 transformações pelas quais passavam os interiores domésticos entre fins do século XVIII e as décadas iniciais do século XIX: 1. a mobília indica a difusão de conjuntos de móveis de uniformidade decorativa nas residências; 2. a especificação mobília de sala aponta para a individuação dos aposentos à medida que a casa se abria para o convívio social; 3 . a palhinha corresponde à disseminação da matéria prima empregada no revestimento do mobiliário de assento que concorreu para a conformação de novas formas de interação social. ${ }^{7}$

Embora a difusão de mobílias nos interiores domésticos ao longo do século XIX fosse uma realidade, esse fato, por si só, não era exclusividade no cenário urbano paulistano no alvorecer dos oitocentos, pois a consulta a inventários abertos no século XVIII revelou que, embora raros, já havia disposições de peças de mesmo estilo e material, pelo menos nas residências da elite mercantil.

6 Relatório anual referente ao ano de 1923. Revista do Museu Paulista, 1926, vol. 14, p.805.

7 Os primeiros assentos empalhados que surgiram em Portugal no quinhentos foram importados da Índia ou da costa oriental africana, pois era corrente a circulação de matérias-primas e de artífices entre as 2 áreas. No final do século XVIII, houve o ressurgimento da utilização da palhinha em Portugal e sua introdução na América Portuguesa, em razão da leveza, arejamento e menor custo do material. FREIRE, 2001, p.28-29. 
No inventário de Ana de Oliveira Montes, esposa do rico comerciante José Rodrigues Pereira, falecida em 1765, por exemplo, encontramos um conjunto composto por 12 cadeiras de jacarandá com seus coxins à moderna, 2 mochos e uma poltrona, irmãos das cadeiras. ${ }^{8}$

Segundo Maria Helena Flexor, também em Salvador, os conjuntos de móveis com elaboração e decoração harmônica "começariam a aparecer, aos poucos, em fins do século XVIII, intensificando-se o uso somente na segunda metade do século XIX" (Flexor, 2009, p.142).

A grande novidade, portanto, no sobrado do Brigadeiro é o conjunto enquadrado por um canapé ou sofá cadeiral, como é denominada no Museu Paulista esta peça de mobiliário, datada do XIX, de madeira de jacarandá, imitando 4 cadeiras alinhadas e unidas (Rodrigues, 1948).

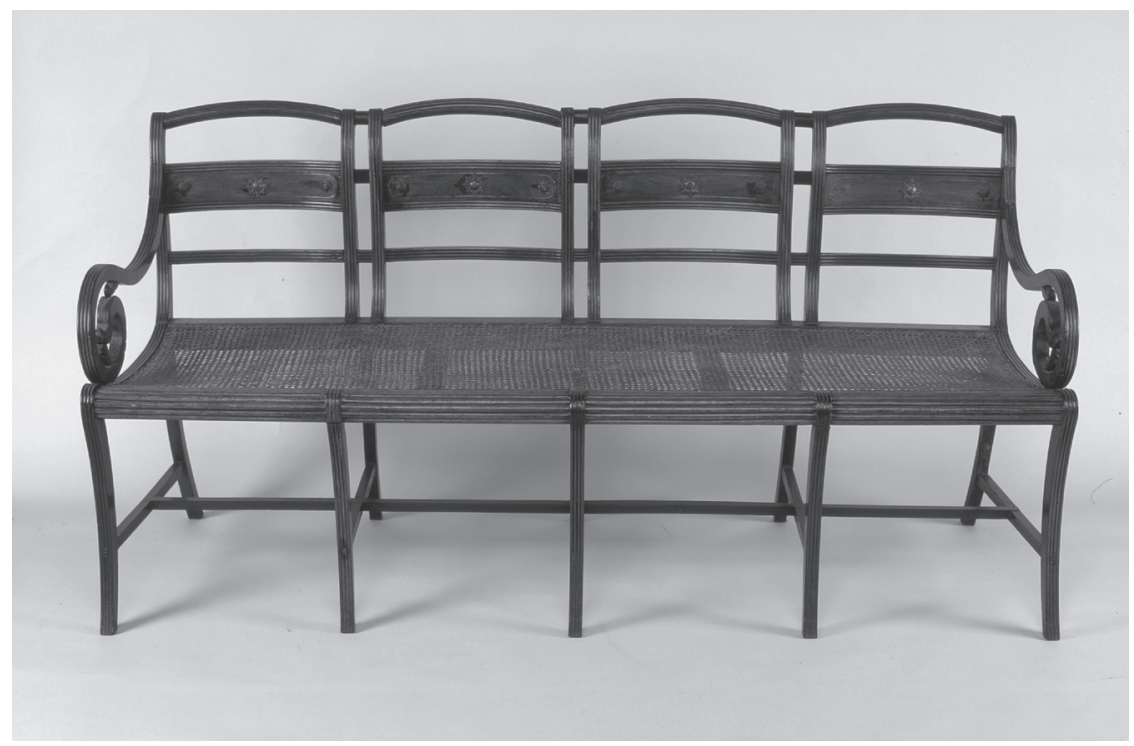

Figura 2 - Sofá tipo cadeiral - séc. 19. Acervo Museu Paulista/USP. Fotografia de Hélio Nobre.

8 Arquivo Público do Estado de São Paulo. Ana de Oliveira Montes: Inventários e testamentos - Juízo de Órfãos, C00664 - 1765. 
Ainda que em Portugal canapés semelhantes a este já fossem confeccionados desde a segunda metade do século XVIII, com assento forrado de tecido ou de palhinha (Freire, 2001; Pinto, 2005), em São Paulo esses móveis estrearam nas salas de visitas somente nos inícios dos oitocentos, reproduzindo a forma e a decoração das cadeiras que lhes ladeavam.

No sobrado do Brigadeiro, nos deparamos com 3 conjuntos de móveis em 3 salas distintas, cada uma das quais sendo descritas em seu inventário a partir das cadeiras de palhinha que lhe recheavam seguidas dos canapés "irmãos das cadeiras", ou "canapés companheiros das cadeiras".

De fato, o emprego mais disseminado da palhinha no mobiliário de assento era praticamente uma inovação no alvorecer do século XIX. Nos inventários consultados para a realidade paulistana dos setecentos, localizamos apenas um móvel com o revestimento do assento em palhinha. Trata-se de um mocho pertencente ao capitão José Barbosa de Lima, proprietário de terras e de uma venda, falecido em $1755 .{ }^{9}$

Mas é bom não se esquecer de que as cadeiras de palhinha - típicos móveis leves e ligeiros - conviveram durante muito tempo com cadeiras de sola, tamboretes, mochos, estrados e esteiras, senão no mesmo aposento, certamente no mesmo ambiente, uma vez que, na América Portuguesa, até este período, as mulheres sentavam-se à maneira asiática, vinculada à cultura lusitana de influência árabe (Carvalho, 2008, p.199).

Se as pessoas - sobretudo as mulheres - se sentavam no chão para fiar, costurar, bordar, preparar alimentos, é de se supor que aí realizassem refeições. De fato, são recorrentes os comentários dos viajantes sobre tais práticas nos mais distintos lugares do país ainda nas primeiras décadas do século XIX. ${ }^{10}$

Referindo-se à casa de um senhor de engenho, em 1802, Thomas Lindley comentou que achara "as acomodações da casa muito superiores

9 Arquivo Público do Estado de São Paulo. José Barbosa de Lima: Inventários e testamento Juízo de Órfãos, C00686 - 1755.

10 Para a compreensão da literatura de viagem e dos viajantes que estiveram no Brasil em fins do século XVIII e XIX, ver os trabalhos de LISBOA, 1997; SELA, 2001; TORRÃO FILHO, 2010. 
ao que havia esperado encontrar, dada a pobreza geral de Porto Seguro (...). Jantamos no chão, sendo estendidas umas esteiras e, sobre elas, uma toalha limpa". ${ }^{11}$

Sobre os costumes femininos em Salvador, Tollenare, em 1817, disse que a "senhora vai à missa, seguida de numerosos escravos ricamente aparamentados e, de volta à casa, senta-se num esteira e come a farinha de mandioca com os dedos". ${ }^{12}$ Sua gravura "Repas d'une dame brésilienne" ilustra esse comentário ao retratar uma senhora sentada sobre a esteira, fazendo a refeição sem ajuda de talhares, tendo à sua volta 4 escravas jovens a servi-la (Koutsoukos, 1994).

Na região sul do país, Auguste de Saint-Hilaire, nos anos 1810, também se deparou com os mesmos comportamentos. Sobre as práticas alimentares nos arredores de Florianópolis, assinalou: "Cada sítio se compõe de uma casa construída de barro e paus cruzadis, sendo porém, coberta de telhas, caiada e bem conservada. Os móveis não são mais comuns do que nas pequenas habitações do interior e consistem geralmente em alguns tamboretes, uma mesa, uma esteira em que as mulheres trabalham acocoradas e também toda a família faz as refeições" ${ }^{13}$ Aludindo ao pouso numa palhoça perto de Torres, registrou: "Enquanto escrevo estendem uma esteira no chão e aí servem a sopa, reunindo-se toda a família em torno da esteira". ${ }^{14}$

No Rio de Janeiro, na década de 1820, Jean-Baptiste Debret igualmente flagrou momentos de comensalidade no interior de uma casa de ciganos, para os quais teceu os seguintes comentários: "nessas esplêndidas refeições, os convivas sentam-se sobre esteiras postas no chão,

11 LINDLEY, Thomas. Narrativas de uma viagem ao Brasil (1802-1803). São Paulo: Companhia Editora Nacional, 1969, p.42.

12 TOLLENARE, Louis François de. Notas dominicais tomadas durante uma viagem em Portugal e no Brasil em 1816, 1817 e 1818. Salvador: Livraria Progresso Editora, 1956, p.332.

13 SAINT-HILAIRE, Auguste de. Viagem à Província de Santa Catarina (1820). São Paulo: Companhia Editora Nacional, 1936, p.160.

14 SAINT-HILAIRE, Auguste de. Viagem ao Rio Grande do Sul (1820-1821). Belo Horizonte: Itatiaia; São Paulo: Edusp, 1974, p.19-20. 
em torno de uma toalha onde se colocam as comidas" (Bandeira; Lago, 2013, p.183). ${ }^{15}$

A partir das descrições de Thomas Lindley para Porto Seguro, Tollenare para Salvador, Saint-Hilaire para Santa Catarina e Debret para o Rio de Janeiro, 3 pontos merecem ser destacados: a versatilidade do local das refeições, realizadas onde se "colocava a mesa" pelo mero estender de uma toalha sobre a esteira; a difusão do comer sobre o chão entre pessoas de várias camadas sociais; a prática da comensalidade, agregando os membros da família em torno das refeições, ainda que acocorados ou sentados “à asiática”.

Quando voltamos os olhos para o contexto paulista dos séculos XVIII e inícios do XIX quais referências encontramos sobre a prática do sentar-se à asiática e do comer sobre chão? Bem, se nos baseássemos tão somente nas impressões deixadas pelos viajantes, muito pouco teríamos a dizer. Manuel Cardoso de Abreu, John Mawe, Gustavo Beyer, Alcide D’Orbigny, Auguste de Saint-Hilaire, Daniel Kidder que visitaram a cidade de São Paulo naquele período, praticamente nada relataram sobre o mobiliário de assento utilizado durante as práticas alimentares.

Também nos inventários consultados entre as décadas de 1740 e $1840,{ }^{16}$ nenhuma esteira foi listada. Isso não significa, porém, que não se sentasse à maneira asiática, haja vista a disseminação e permanência dessa prática em todos os estratos sociais, tanto em espaços domésticos como religiosos.

Sua difusão nos espaços públicos pode ser verificada na gravura de Hercules Florence, "A inocência sobre o túmulo de um ilustre liberal", datada de 1830, em que foi retratada uma cena de homenagem póstuma sobre o túmulo de Líbero Badaró, na primitiva Igreja da Sé. Nela doze mulheres estão sentadas à asiática, com as pernas cruzadas, cobertas

15 Imagem disponível em: http://www.brasiliana.usp.br/bbd/handle/1918/624520055; Acesso em: 23 out. 2015.

16 Foram consultados 87 inventários post mortem de indivíduos de vários segmentos sociais residentes em São Paulo, guardados no Arquivo Público do Estado de São Paulo (APESP) e no Arquivo do Tribunal de Justiça do Estado de São Paulo (ATJESP). 
por mantos de baeta e mantilhas (Marins, 2008). Já sua propagação pelos grupos sociais pode ser atestada por meio da descrição feita por Isabel Burton, esposa de Richard Burton, sobre a recepção dada a ela pela Marquesa de Santos, em 1865: "a última vez em que a vi recebeu-me na intimidade de sua cozinha, onde sentava no chão, fumando, não um cigarro, mas um cachimbo" (Burton, apud Carvalho, 2008, p.207).

Para além do chão batido e das esteiras, as mulheres sentavam-se em estrados. Este costume tem origem no Oriente, foi largamente adotado em Portugal e Espanha, em razão de séculos de dominação árabe na península e foi transplantado para a América Portuguesa. Sobre os estrados, em geral dispostos junto às paredes, várias atividades se desenrolavam dependendo da hora do dia - costurar, comer, dormir (Flexor, 2009).

Em "Família pobre em casa", pintada por Debret na década de 1830, observa-se o interior da moradia de uma velha senhora, e sua jovem filha ou neta em companhia de uma escrava. No primeiro plano, a jovem está sentada numa esteira onde fabrica renda e a anciã está sentada num estrado de madeira. Ela tem em suas mãos um tipo de cajado, enrolado com uma espécie de tecido ou fios de algodão ou lã, o que sugere que ela deve estar fiando também.

Para o caso paulistano, estrados foram mencionados nos inventários e é provável que, além das funções descritas acima, fossem usados para as práticas alimentares.

Obviamente, possuir um estrado não significava não possuir outros móveis de assento ou de suporte, usados para o comer e o beber, mas no caso em que foram registrados somente estrados sem que mesas ou bufetes lhes fizessem companhia, houve menção a toalhas de mesa, o que sugere que algumas refeições fossem feitas sobre eles. Foi o que aconteceu, por exemplo, no caso de Domingos Lobo de Oliveira, cujo inventário aberto em 1750, trazia "um estrado de 2 tábuas", "uma sobretoalha toda rendada, uma toalha de bretanha [rasgada de usar], uma toalha de algodão rendada em bom uso.". ${ }^{17}$

17 APESP - Inventários e testamentos - Domingos Lobo de Oliveira - 1750. 
Mais interessante ainda são os casos em que não há menção a mesas, bufetes e estrado e há registro de toalhas de mesa, indicando talvez a prática de comer sobre o chão. Enquadrados nesta condição, tanto no inventário de João do Prado de Siqueira, aberto em 1742, como no de Manuel Luis da Costa, datado de 1755, foram registradas toalhas de mesa de Guimarães com 6 guardanapos. ${ }^{18}$

Para que se possa imaginar o estrado no interior de um recinto, é importante dizer que suas dimensões registradas nos inventários paulistas variavam entre 7 a 11 palmos de comprido por 3 a 8 palmos de largura, ou seja, mediam de $1,54 \mathrm{~m}$ por $0,66 \mathrm{~m}$ a $2,42 \mathrm{~m}$ por $1,76 \mathrm{~m}$, comportando, por vezes, várias pessoas sobre sua superfície.

Os registros de estrados, bancos, tamboretes e cadeiras sugerem que as refeições poderiam se realizar em variados locais, dependendo dos comensais, da hora do dia e dos pratos servidos. Mas não só. Indicam ainda o uso diferenciado de peças de mobiliário de acordo com os afazeres cotidianos, insinuando que a versatilidade de alguns móveis de assento - comum nas residências marcadas pelo despojamento material - começava a rumar em direção à especialização de seu uso social de acordo com o estrato social a que pertenciam seus detentores.

O sentar-se tradicional, especialmente aquele que dispensava o uso de mobiliário, como era o caso da postura asiática, sobretudo praticado pelas mulheres, passou a ser estigmatizado no decorrer do século XIX por várias razões.

Segundo Vânia Carvalho, a primeira delas, refere-se a uma associação equivocada da postura à preguiça e ao ócio. A segunda tem a ver com a explicitação de formas de distinção social também nos interiores domésticos. Uma delas era exibir atitudes corporais elegantes no sentar-se. Consequentemente, as posturas agachadas ou o uso do chão passaram a ser vistos como uma maneira rude, associada à pobreza e à falta de mobiliário (Carvalho, 2008, p.206-207).

18 APESP - Inventários e testamentos - João do Prado de Siqueira - 1742; APESP - Inventários e testamentos - Manuel Luis da Costa - 1755. 
Datada de 1823, a obra "Uma senhora de algumas posses em sua casa", de Jean Baptiste Debret, ${ }^{19}$ nos dá conta das mudanças pelas quais passava $\mathrm{o}$ ato de sentar. A mulher retratada saiu do solo para a marquesa sem, contudo, abandonar a maneira asiática de sentar, enquanto as escravas permaneceram no chão, sobre as esteiras. Enquanto costurava e ensinava as primeiras letras à filha, igualmente sentada à asiática, mas numa cadeira rasa, aguardava o refresco que lhe trazia o cativo.

A manutenção da postura corporal autossustentada feminina em móveis de assento nas horas das refeições também nos é dada a conhecer pelos registros do artista francês. Sobre o humilde jantar de um pequeno negociante do Rio de Janeiro, comenta: "Essa refeição simples, repetida invariavelmente todos os dias e cuidadosamente escondida dos transeuntes, é feita nos fundos da loja, numa sala que serve igualmente de quarto de dormir. O dono da casa come com os cotovelos fincados na mesa; a mulher com o prato sobre os joelhos, sentada à moda asiática na sua marquesa, e as crianças, deitadas ou de cócoras nas esteiras, se enlambuzam à vontade com a pasta comida nas mãos". ${ }^{20}$

No acervo do Museu Paulista, contamos com marquesas, porém, infelizmente, não temos exemplares de esteiras, estrados e redes datados do século XVIII e XIX. Tal lacuna, entretanto, não inviabiliza conjecturas sobre as práticas alimentares e de convívio social nos interiores domésticos, pois dispomos de outros móveis de assento que são bastante instigantes para desenvolver de forma mais concreta a ideia acerca do papel dos artefatos como mediadores de relações pessoais e conformadores de práticas sociais no momento de transformações das dinâmicas sociais em São Paulo, em especial no âmbito das elites, em fins do período colonial.

$\mathrm{Na}$ instituição, encontramos, por exemplo, "uma cadeira de jacarandá, do século XVII, em linhas retas, de construção rústica, assento

19 Imagem disponível em: http://www.brasiliana.usp.br/bbd/handle/1918/624520053; Acesso em: 23 out. 2015.

20 DEBRET, Jean-Baptiste. Viagem Pitoresca e Histórica ao Brasil (1816-1831). São Paulo: Martins Editora, 1940, p.139. 
e espaldar guarnecidos de sola lavrada com cercadura e ramagens; no centro do espaldar, cartela com flores com o monograma "AP". Nos ângulos, remate de madeira em ectaedro. Pregaria de pequenas cabeças de latão. Pernas retas, angulares, com travessas simples" (Rodrigues, 1948, f.29). Ela pertencera ao bisavô materno de D. Francisca Miquelina, Antonio de Barros Penteado, sogro do Brigadeiro Luis Antonio. Foram cadeiras semelhantes a essa as primeiras a penetrarem nos ambientes domésticos paulistas, como já salientara Vânia Carvalho (2008).

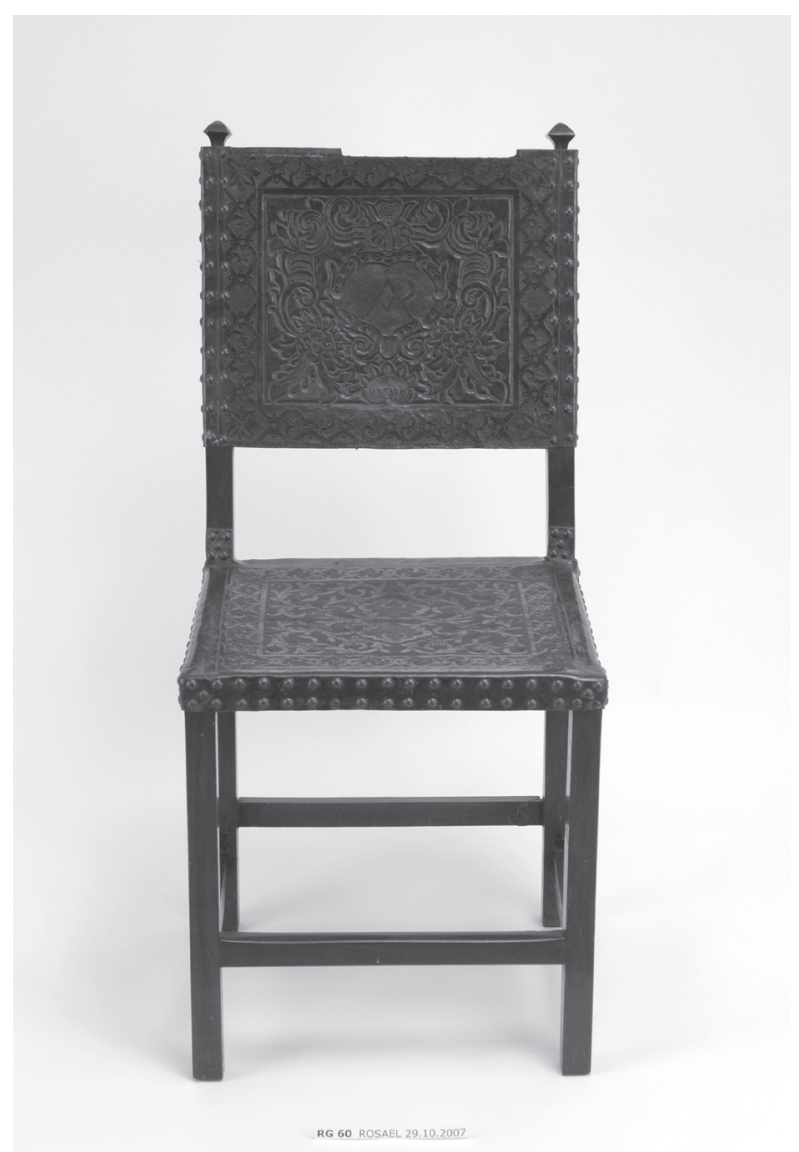

Figura 3 - Cadeira - séc. 17. Acervo Museu Paulista/USP. Fotografia de Hélio Nobre. 
Também dispomos no acervo de um novo estilo de cadeira de sola que adentrou as residências na segunda metade do século XVIII e nelas permaneceram pelos oitocentos afora. Trata-se de um exemplar confeccionado em jacarandá, datado do século XVIII, com assento de sola lavrada, espaldar de madeira vasado e pernas arqueadas com pés redondos.

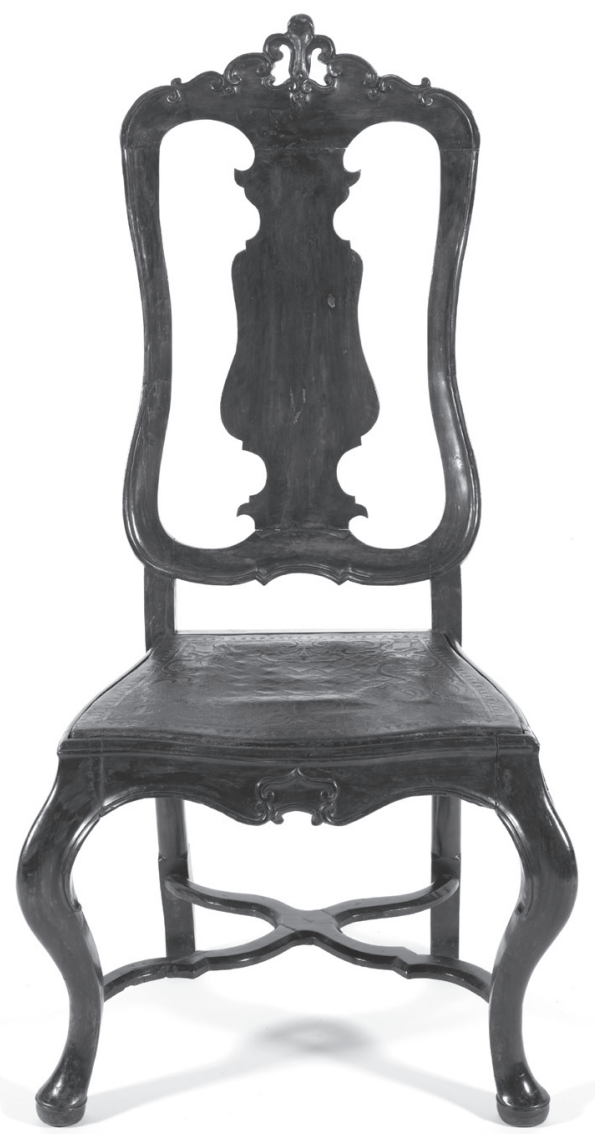

Figura 4 - Cadeira - séc. 18. Acervo Museu Paulista/USP. Fotografia de Hélio Nobre. 
Cadeira semelhante a essa foi eternizada por Thomas Ender, ao retratar "Uma sala de estar em São Paulo", em 1817. Ainda que seja o único móvel do aposento, o qual prima pela austeridade material, bem se vê que não se tratava de uma residência pobre, levando-se em conta as dimensões da sala, o chão assoalhado e o teto forrado. Ademais, ao incluir as conversadeiras na cena, situadas abaixo do peitoril das janelas de treliças, o artista indicou que as relações sociais, naquele início de século, ainda muito se desenvolviam no mundo exterior às moradias, mas não deixavam de envolver moradores que interagiam com os transeuntes, seja por meio da troca de palavras ou simplesmente de olhares. Nesse sentido, como bem analisou Paulo Garcez Marins, as rótulas eram artefatos que funcionavam como instrumentos de mediação entre os espaços públicos e privados, e não de segregação como longamente apontado pela historiografia (Marins, 1999).

Colocadas junto às paredes, as cadeiras de sola não se adequavam muito a deslocamentos em razão do peso e exigiam posturas físicas mais protocolares devido à própria estrutura dos móveis. É difícil imaginar que peças como estas, pesando de $6,730 \mathrm{~kg}$ a $9,430 \mathrm{~kg}$ fossem frequentemente movimentadas nas salas da frente e/ou circundassem mesas. Esse comentário, entretanto, não significa que os interiores domésticos setecentistas não se prestassem a abrigar reuniões sociais, pelo menos no caso dos comerciantes e/ou de suas viúvas, haja vista que foram localizadas casas de moradas abrigando mais de uma dezena de cadeiras e tamboretes.

Se as descrições dos móveis de assento nos inventários setecentistas e do início do XIX consultados não esclarecem quais deles eram usados junto às mesas para refeições, a aquarela "Um jantar brasileiro", de Jean -Baptiste Debret, pintada em 1827 - uma das imagens mais difundidas pelos livros de História para tratar das relações cotidianas do Brasil Colonial - pode nos fornecer indícios sobre as características das peças utilizadas no Rio de Janeiro oitocentista e nos auxiliar a conjeturar sobre o emprego dos artefatos na realidade paulistana, ao menos nas casas dos segmentos mais abastados da população. ${ }^{21}$

21 Imagem disponível em: http://www.brasiliana.usp.br/bbd/handle/1918/624520055; Acesso em: 23 out. 2015. 
Ao atentarmos para a cadeira em que está sentado o marido, notamos que seus atributos físicos - o encosto vasado e as pernas curvas sem travessas - diferem das cadeiras de sola comentadas anteriormente. Ainda que não nos seja dado a ver o assento, ela muito se assemelha às cadeiras de palhinha, introduzidas na América Portuguesa em inícios do século XIX, como o exemplar pertencente ao Brigadeiro, guardada no Museu Paulista.

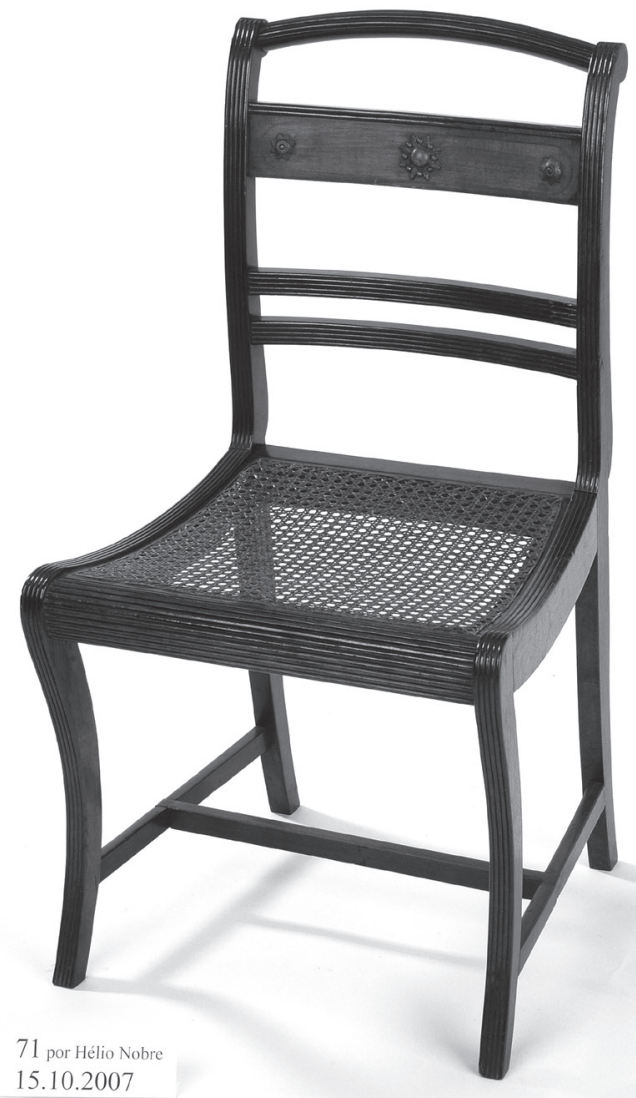

Figura 5 - Cadeira - séc. 19. Acervo Museu Paulista/USP. Fotografia de Hélio Nobre. 
No Museu de Artes Decorativas de Paris, uma peça de assento e espaldar de palhinha, confeccionada por Claude Etienne Mechard (1732-1794), foi denominada como "chaise de salle a manger", o que reforça seu emprego na hora das refeições principais do dia.

O exemplar que se encontra no Museu Paulista, por sua vez, devia ser usado em outras ocasiões de interação social e de práticas alimentares, num dos cômodos de receber elencados no inventário do Brigadeiro, nos quais curiosa, mas não surpreendentemente, não foram avaliadas mesas de jantar.

As cadeiras de palhinha, como eram chamadas, vieram a favorecer as situações de convívio social. Isso porque a adoção da palhinha como revestimento reduziu o peso estrutural da cadeira e a linha curva das pernas dispensou o sistema de travação, dando leveza e agilidade ao artefato, que agora poderia ser movimentado nos recintos favorecendo a intensificação de relações interpessoais (Madureira, 1992, p.176).

Os exemplares de palhinha guardados no Museu Paulista, por exemplo, pesam $4,350 \mathrm{~kg}$, cerca de $50 \%$ mais leves que a de sola. Tais modelos, portanto, instavam o corpo para práticas de sociabilidade, condicionando a maneira de estabelecer o contato com outras pessoas (Carvalho, 2008, p.211), fosse na sala de visitas ou de na de jantar, ladeando sofás ou circundando mesas.

Os inventários consultados abertos nas 4 primeiras décadas do XIX já evidenciam que este tipo de móvel estava mesmo se difundindo naquela época, figurando em maior número nas residências paulistanas, em recintos onde se podia conversar, jogar, tomar bebidas, fazer negócios, tecer articulações políticas. No sobrado do Brigadeiro Luis Antonio, as cadeiras de palhinha estavam espalhadas nos 3 aposentos destinados à recepção - 12 na sala do canto, 16 na sala do oratório e 12 na sala da senhora.

Mas seu caso não era único, nem exceção entre as residências da elite. No inventário de Manuel Rodrigues Jordão, aberto em 1828, parte do mobiliário foi descrita por sua alocação na varanda, em 8 salas, nos quartos de hóspedes e no escritório. Tal como o brigadeiro Luis Antonio, o brigadeiro Jordão, foi grande comerciante e proprietário de 
terras, falecido em 1828, com monte-mor também avaliado em cerca de 300 contos de reis. Em seu sobrado, localizado nos Quatro Cantos - cruzamento das ruas Direita e São Bento -, foram contabilizados 215 móveis de assento com predomínio da palhinha em 136 das 170 cadeiras registradas. ${ }^{22}$

O inventário de D. Genebra de Barros Leite, viúva do Brigadeiro Luis Antonio, igualmente mostra o crescimento das atividades de salões na cidade de São Paulo no decorrer do século XIX. ${ }^{23}$ D. Genebra se unira em segundas núpcias ao baiano José da Costa Carvalho, bacharel por Coimbra e figura de imensa projeção política no Império, recebendo sucessivamente os títulos de barão, visconde e marquês de Monte Alegre. Segundo Paulo Cesar Garcez Marins, "suas atividades políticas foram suficientemente intensas para que os salões do sobrado das ruas do Ouvidor e São Bento fossem amplamente frequentados pelos membros das elites da cidade e da província" (Marins, 2005).

Os eventos sociais certamente eram permeados por comes e bebes, haja vista que o número de móveis de assento na residência da rua do Ouvidor passou de 40 em 1819 para 80 em 1838, ano da morte de D. Genebra, dispostas sobretudo na primeira, segunda, terceira, quarta, quinta sala e varanda, e que foram arroladas, por exemplo, cerca de 200 garrafas de vinho em caixões e armários e 40 latas de chá, estas últimas já observadas por Paulo Garcez Marins (2005).

Ainda que alguns documentos dos inícios dos oitocentos já trouxessem os móveis descritos de acordo com sua posição nos aposentos, como nos do Brigadeiro Luis Antonio e de D. Genebra, isso não era regra geral, pois muitas vezes avaliavam-se os móveis pelo material empregado, no caso madeiras, como no do Brigadeiro Jordão. Em razão desta organização presente em muitos processos, não se espere encontrar nas fontes a função utilitária mais específica de cada uma das cadeiras.

22 Arquivo do Tribunal de Justiça do Estado de São Paulo. Manuel Rodrigues Jordão: Inventários do $1^{\circ}$ cartório de família, proc. 229 - 1828.

23 Arquivo do Tribunal de Justiça do Estado de São Paulo. Genebra de Barros Leite: Inventários do $1^{\circ}$ cartório de família, proc. 531 - 1838. 
Talvez, a própria versatilidade de seu uso social dificultasse descrições precisas. O mesmo não acontecia, entretanto, com os registros de alguns móveis de suporte nestes mesmos processos do século XIX, notadamente as mesas.

Desde fins do século XVIII, as mesas foram, aos poucos, se tornando parceiras dos pesados bufetes como móveis de suporte nas residências paulistanas. No acervo do Museu Paulista, dispomos de 3 exemplares de bufetes datados dos séculos XVII e XVIII, cujas características são a madeira de jacarandá, as gavetas, os pés torneados ligados por travessas. Já a mesa de sofá do Brigadeiro Luis Antonio, ainda que de dimensões semelhantes, apresenta as inovações dos móveis de suporte ligeiros, caracterizados pelos 2 suportes em tábua grossa, apoiados, cada um em 2 pés arqueados e presos entre si por uma travessa torneada. $\mathrm{O}$ tampo tem abas móveis nas extremidades, de cantos redondos. ${ }^{24}$

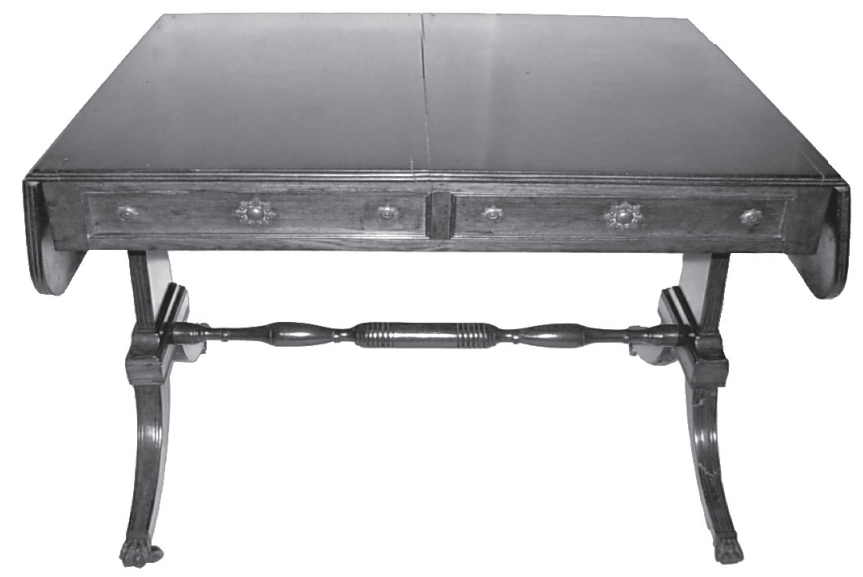

Figura 6 - Mesa: console - séc. 19. Acervo Museu Paulista/USP. Fotografia de Hélio Nobre.

24 A mesa de sofá - tradução do termo inglês sofa-table - corresponde a uma mesa multifuncional, alta e estreita, com gavetas, em geral disposta em salas de visita, atrás do sofá, cujos utensílios, colocados em seu tampo, seriam de fácil acesso aos usuários do sofá. Conforme informações retiradas de Banco de dados e imagens do Museu Paulista-USP. 
Novamente, para que se avaliem os pesos do bufete e da mesa, ambos inegavelmente utilizados como apoio, mas não necessariamente como móvel para refeição, basta que se diga que o bufete do Museu Paulista pesa cerca de $80 \mathrm{~kg}$ e a mesa de sofá $30 \mathrm{~kg}$. As mesas, portanto, adquiriram maior leveza, servindo como apoio para os vários conjuntos de assentos espalhados pelas salas abertas a um público maior.

Embora houvesse uma proliferação de móveis de suporte no espólio do Brigadeiro Jordão, apenas uma mesa foi rotulada para o jantar. "Trata-se de uma mesa grande, que serve para jantar, de abrir”. Esta última característica também foi registrada em mais 2 mesas, uma "de jacarandá, de abrir, com seus embutidos e com gavetas" e a outra "redonda de jacarandá preto, de abrir", o que sugere que também pudessem ser utilizadas para refeições principais, adequando-se ao número de comensais.

No caso do Brigadeiro Luis Antonio, 2 mesas de jantar foram registradas com 2 gavetas cada - não nas salas principais, mas no item "Mais móveis" - uma das quais parece reaparecer no inventário da viúva, também em local indefinido, como "mesa velha de jantar com gaveta", avaliada proximamente a outras peças relacionadas a momentos de refeição, como "uma mesa de jantar de três peças", "2 aparadores de madeira de óleo", "um guarda louça com 2 gavetas", "2 armários de canto com suas vidraças". Ainda, em 1838, na varanda, foram flagradas 11 cadeiras de madeira de jacarandá com assento de palhinha, já usadas com pés torneados, uma mesa de abrir de baeta verde e uma mesa redonda de abrir, sugerindo que aí também fosse um local de ocorrência de práticas alimentares.

A designação "de jantar" remete a um móvel particular para determinada função rodeado por móveis de assento que lhe são igualmente próprios, o que, na América Portuguesa do início dos oitocentos, não implica necessariamente a existência de uma sala específica destinada à refeição principal, como se constata pelo arrolamento de bens do casal, com intervalo de 20 anos.

Ao estudar as casas das elites lisboetas entre 1750 e 1825, Carlos Franco comentou que as primeiras salas de jantar demarcadas nos interiores domésticos não foram necessariamente concebidas para receber, daí 
contarem com pé direito baixo e se localizarem em antigas zonas de serviço da casa, contíguas às cozinhas (Franco, 2011, p.93-95). Para o contexto colonial, tal descrição parece indicar que esse recinto de nova nomenclatura, na verdade, vinha a substituir a tradicional varanda das moradias urbanas, que, segundo Vânia Carvalho, era um ambiente interiorizado, "multifuncional e informal, ocupado intensamente pela mulher, que a utilizava como ponto estratégico para o acompanhamento dos trabalhos domésticos e para a recepção de visitas íntimas" (Carvalho, 2008, p.120).

Ainda que não contasse com recinto próprio, a mesa de jantar que começa a figurar nos inventários da elite residente na São Paulo oitocentista parece se distanciar da conhecida mesa, "móvel da casa em que se põem os pratos para comer,", 25 tornando-se peça central para a prática social de ritos alimentares mais regrados a serem partilhados por pessoas alheias ao núcleo familiar. Ritos esses promovidos pelos homens de negócio, muitos dos quais herdeiros de fortunas dos seus antepassados ou dos de suas esposas, dedicados à lide mercantil, que passaram a conjugar as antigas atividades comerciais com a agricultura de exportação de açúcar, difundindo novas formas de sociabilidade em suas residências.

Francisco de Castro Canto e Melo, responsável pela descrição da viagem do príncipe regente a São Paulo em 1822, admirado com a recepção dada pelo Brigadeiro Jordão a D. Pedro, qualificou-a como "obsequiosa e magnífica hospedagem". ${ }^{26} \mathrm{~A}$ incorporação do brigadeiro Jordão ao grupo de D. Pedro na viagem à vila de Santos, no dia seguinte à acolhida e às vésperas da proclamação da independência, dá conta de como os interiores domésticos se tornavam mais e mais palco para o desenvolvimento de relações sociais e de poder.

Impressão diferente teria Daniel Kidder sobre o almoço do qual participara numa fazenda de D. Gertrudes Galvão de Oliveira Lacerda,

25 BLUTEAU, Raphael. Vocabulario portuguez \& latino: aulico, anatomico, architectonico..., 10 vols., vol. 5. Coimbra: Collegio das Artes da Companhia de Jesus, 1712-1728, p.446.

26 MELO, Francisco de Castro Canto e. Descrição da viagem do príncipe do Rio de Janeiro a São Paulo, feita pelo gentil-homem de sua câmara Francisco de Canto e Melo. In: MORAES, Alexandre José de Mello. História do Brasil-Reino e Brasil-Império. Belo Horizonte: Itatiaia; São Paulo: Edusp. 1978. p.428-432, p.428. 
viúva do Brigadeiro Jordão, no final da década de 1830. Diz ele: "Seguimos viagem pela manhã seguinte bem cedo e lá chegamos ainda a tempo para o almoço. Nessa refeição tomaram parte cerca de vinte pessoas, todas sentadas em bancos, ao longo de uma comprida mesa fixa no chão". ${ }^{27}$ Nas páginas seguintes, continua "era rico e farto o serviço de mesa, mas reinava certa confusão entre as dez ou doze copeiras (...) A baixela era das mais finas e caras. As mesas e cadeiras, miseráveis". ${ }^{28}$

Como o desenvolvimento das ações humanas não é linear e unidirecional, tais impressões nos revelam a ambivalência dos artefatos e das práticas sociais em torno das refeições nas primeiras décadas do XIX. Mostram como os novos recintos e móveis destinados a momentos de interação social, muitas vezes, se limitavam a alguns sobrados localizados no centro da capital, palcos privilegiados de reuniões necessárias à própria articulação social e política das novas elites paulistanas (Marins, 2005).

Tal como a mesa de jantar passou a designar um determinado móvel cada vez mais afastado das antigas mesas de pau ou da improvisação de tábuas sobre cavaletes, no caso dos rituais do chá, podemos dizer que os eventos igualmente concorreram para a introdução de peças específicas - as mesas de chá -, transformando um hábito antes restrito ao cotidiano familiar em evento de forte conotação social. Segundo Maria Alexandre Lousada, foi, sobretudo, a partir do reinado de D. José I (1750-1777) que se institucionalizou uma nova dinâmica nos ritos alimentares das elites citadinas portuguesas com a introdução de tertúlias vespertinas, regadas a chá ou chocolate, torradas e doces (Lousada, 2004). ${ }^{29}$

27 KIDDER, Daniel. Reminiscências de viagens e permanências no Brasil. São Paulo: Edusp, 1972, p.194.

28 KIDDER, 1972, p.203.

29 "O século XIX trouxe as transformações que ainda hoje fazem parte do nosso mundo. Os horários das refeições foram alterados para as horas que conhecemos hoje devido à introdução da iluminação a gás, depois à eletricidade e também à ausência dos homens da casa, nos negócios ou no emprego durante o dia. (...) Assim, a primeira refeição do dia, ligeira na Europa continental, passou a chamar-se pequeno almoço, o almoço ficou mais tardio, tomando o lugar que era do jantar, este, entrou na noite confundindo-se com a ceia. A nível familiar ou social manteve-se como a mais importante refeição do dia" (VALENÇA, 2002, p.8-9). 
Nesses casos, parece claro que os móveis de suporte não podem ser desvinculados dos de assento. As mesas supostamente destinadas à cerimônia do chá na casa do Brigadeiro Jordão foram assim descritas em seu inventário: "mesa redonda, de óleo, de chá", "mesa também de chá, de madeira vapuã”. Embora não possamos afirmar em que sala ela acontecia, os registros evidenciam que as mesas destinadas ao ritual não eram as salas de jantar, como apontado por Tânia de Andrade Lima para o contexto fluminense oitocentista (Lima, 1997).

Na residência do Brigadeiro Luis Antonio, por sua vez, a mesa de chá fora registrada como redonda de jacarandá - também arrolada no item "Mais móveis" como as mesas de jantar - e não na sala da senhora como era de se esperar, ainda que se imagine que este recinto era destinado, entre outras funções, a protagonizar o ritual do chá, tão presente no decorrer do século XVIII na Inglaterra e difundido no Rio de Janeiro com a chegada da Família Real. Para além da especificidade da mesa e do nome da sala, tal suposição decorre da existência de 2 aparelhos de chá, sendo um de louça da Índia e outro de prata, este último novamente mencionado no inventário da viúva, falecida 20 anos depois, sem contar as latas de chá já citadas.

Infelizmente dispomos de pouquíssimas impressões sobre as ocasiões que envolviam a ingestão de chá em São Paulo em inícios do XIX. Tal prática foi lacônica e imprecisamente referida por John Mawe, que visitou a cidade em 1807, ao comentar a importância das festas religiosas no cenário urbano paulistano: "as senhoras, que consideram o dia como de festa, em seus vestidos de gala, enchem as sacadas das casas, de onde se tem melhor visão do espetáculo; a noite termina, em geral, com chá e partidas de cartas ou danças". ${ }^{30}$ Já Saint-Hilaire se referiu à ingestão de chá quando foi levado à casa do ouvidor no dia em que chegara à cidade de São Paulo em 1819, que "lhe recebeu cortesmente, convidando-o para tomar chá em sua companhia”. ${ }^{11}$

30 MAWE, John. Viagens ao interior do Brasil (1807-1810). Belo Horizonte: Itatiaia; São Paulo: Edusp, 1978, p.72.

31 SAINT-HILAIRE, Auguste de. Viagem à província de São Paulo. Belo Horizonte: Itatiaia; São Paulo: EDUSP, 1976, p.142. 
Embora ausentes nas descrições acima, parece legítimo supor que as cadeiras, tamboretes e mochos eram os artefatos obrigatórios e quase imprescindíveis nas tertúlias promovidas nas casas da elite, envolvendo bebidas, comidas e jogos de tabuleiro. Nada que impedisse, costumeira e confortavelmente que, no cotidiano diurno, as mulheres lançassem mão de esteiras e estrados para a realização de trabalhos manuais e/ou de determinadas refeições, haja vista a descrição acerca da recepção dada a estrangeiros pela Marquesa de Santos, sentada no chão de sua cozinha.

\section{DO MUSEU AO SOBRADO}

A mobília da sala de visitas do Brigadeiro Luis Antonio integrou a exposição "De pratos, elixires e urinóis no Brasil do século XIX", ${ }^{2}$ inaugurada em 1996 e desmontada em 2013 no Museu Paulista, disposta numa vitrine juntamente com outros utensílios domésticos dos oitocentos.

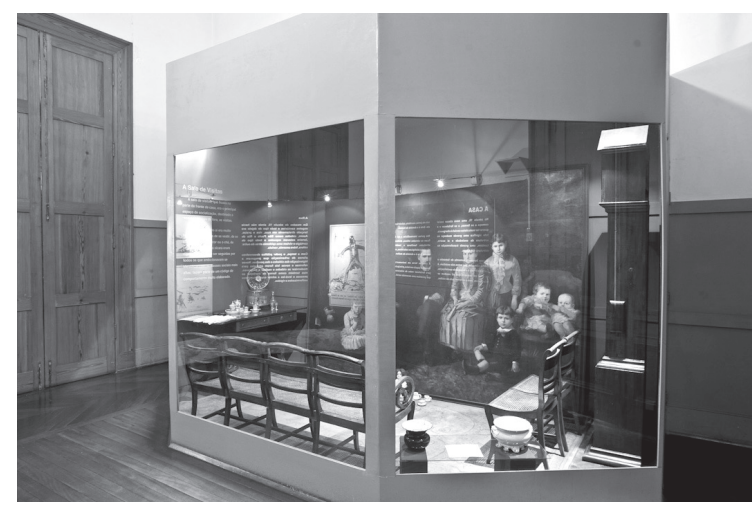

Figura 7 - Exposição "De pratos, elixires e urinóis no Brasil do século XIX", Museu Paulista, 2012. Fotografia de Hélio Nobre.

32 A exposição teve a curadoria original de Tânia Andrade Lima, no contexto de um Pós-Doutorado no Museu Paulista sob Supervisão de Ulpiano T. Bezerra de Meneses e colaboração de Heloisa Barbuy e Ricardo Bogus. Quando o acervo arqueológico do Museu Nacional foi devolvido, a exposição foi adaptada por Heloisa Barbuy e Ricardo Bogus. Agradeço à Profa. Dra. Heloísa Barbuy pelas informações. 
Mas, e no sobrado da esquina das ruas do Ouvidor e de São Bento, onde as peças aqui analisadas estavam dispostas? $\mathrm{O}$ fato é que $\mathrm{o}$ aumento de móveis nos aposentos nos vinte anos que se seguiram à morte do Brigadeiro acabou por dificultar sua localização. Pelo cotejamento das características das peças descritas nos inventários do Brigadeiro e de D. Genebra com as expostas no Museu, elaboramos conjecturas.

$\mathrm{Na}$ sala do canto, foram avaliados, entre outros móveis, 12 cadeiras de palhinha, de madeira preta de jacarandá com seus enfeites de casquinha, 2 canapés irmãos das mesmas cadeiras e uma mesa irmã das cadeiras. A existência dos 3 tipos de móveis - cadeira, canapé e mesa -, aliada aos enfeites de casquinha, que poderiam corresponder aos ornatos de metal aplicados no espaldar das cadeiras, podem ser tomadas como indícios de que fosse nesse aposento que os móveis ficavam dispostos em 1819.

Perseguindo os móveis no inventário de D. Genebra, aberto quase 20 anos depois, parece que conseguimos localizá-los com mais precisão na quarta sala, pela menção a uma mesa de sofá também de madeira de jacarandá com suas estrelas de casquinha e já usada, ao lado de 30 cadeiras de jacarandá de palhinha e do sofá irmão das cadeiras, como já comentado anteriormente.

Em realidade, neste aposento, para além dos móveis citados, havia 2 mesas douradas com tampos de pedra, 4 cantoneiras também douradas com seus tampos de pedra, 2 espelhos grandes com suas molduras douradas, um lustre e uma carteira pequena de madeira com sua fechadura. Todo este recheio indicava grande atividade social, típica da vida de salões, certamente envolvendo chás, chocolates, cafés, refrescos, e seus complementos sólidos (Perez Samper, 2009).

A presença das luxuosas cantoneiras reforça ainda mais a função da quarta sala como ambiente favorável à recepção de visitas e a refeições, uma vez que as louças guardadas nesses móveis de conter eram cuidadosamente arrumadas para exposição. Dispostos, sobretudo, em salas de jantar nas casas das elites lisboetas, Nuno Madureira afirma que a emergência dos guarda-louças e cantoneiras é a prova de que "guardar deixa também de ser um parasita semântico dos verbos depositar e 
conservar, para englobar construções mais dinâmicas: mostrar, expor. (...) Há uma assinatura social, na maneira como se colocam as coisas para serem vistas por outros" (Madureira, 1992, p.192).

Se as cadeiras eram aquelas descritas na sala do canto do tempo do Brigadeiro, não temos como afiançar, ainda que os ornamentos de casquinha lá figurassem. Se isso fosse verdade, temos que aventar 2 hipóteses: primeira - a ordem dos aposentos avaliados em 1819 se manteve em 1838 e os móveis foram deslocados da sala do canto para a quarta sala, originalmente sala da senhora; segunda - e a que tendo a considerar - é a de que os louvados do processo de D. Genebra realizaram outro percurso no interior da residência, alterando a sequência da avaliação das salas de recepção e, nesse caso, a quarta sala corresponderia à sala do canto.

Como já se disse, uma afirmação mais definitiva fica comprometida frente à introdução de muitas e variadas peças de mobiliário nos aposentos que acaba por descaracterizar o recheio original. De toda forma, os móveis descritos nos inventários do casal não deixam margem de dúvida quanto à intensa vida social que se desenvolvia nas 4 salas destinadas à recepção de pessoas alheias ao núcleo familiar, palcos para refeições leves, almoços, jantares e quiçá banquetes - repare-se que aqui nem foram levados em conta os serviços de mesa e as alfaias.

\section{CONSIDERAÇões FINAIS}

Se os interiores domésticos cada vez mais se tornavam espaços para a ampliação de novas formas de convívio social e de relações de poder entre as elites na cidade de São Paulo, retirando do espaço público a exclusividade dos encontros interpessoais, era imperioso que o ambiente da casa e seus proprietários estivessem preparados para dar suporte e difundir comportamentos, mediante novas formas de interação entre corpos e objetos nos momentos sociais que envolviam práticas alimentares.

As peças de mobiliário, descritas nos inventários, nos relatos e gravuras de época, utilizadas - não só, mas também - em momentos de refeições, são testemunhos materiais destas transformações sociais e, por isso, artefatos fundamentais para a compreensão da nova realidade 
socioeconômica que se esboçava na cidade de São Paulo em inícios do século XIX, ancorada nas fortunas provenientes dos negócios de fazenda seca, açúcar, escravos e animais.

Para além do prestígio de que desfrutava em razão dos eventos promovidos e dos ambientes exibidos, ao engajar a casa numa nova rotina de encontros, o grupo mercantil consolidava seu processo de enraizamento urbano e social, protagonizado por portugueses - no caso do Brigadeiro Luis Antonio - ou iniciado pelos antepassados reinóis fixados na capital paulista desde a primeira metade do setecentos - no caso do Brigadeiro Jordão.

Por um lado, a introdução de novos artefatos relacionados à alimentação indica a sintonia das elites comerciais com as mudanças processadas na Europa por meio dos comportamentos adotados pela burguesia ascendente nos ambientes domésticos, no sentido de implantação de novos ritos sociais nos momentos da refeição protagonizados em recintos privados. Por outro lado, a posse de determinados móveis em sobrados da capital paulista impulsiona a implantação de um protocolo urbano que funciona como estratégia de legitimação social, afastando esses homens de negócios de outros segmentos sociais que, no Brasil, ainda em inícios do oitocentos, comiam sentados sobre em esteiras, estrados, redes, marquesas, bancos.

Assim procedendo, os comerciantes acabaram por disseminar comportamentos sociais intramuros bem antes da elite cafeicultora paulista estabelecer residências na capital paulista, garantindo ao espaço urbano maior projeção nacional e internacional e chamando a atenção da historiografia brasileira que, durante boa parte da centúria passada, insistiu em localizar apenas neste contexto o início do desenvolvimento econômico da cidade de São Paulo.

\section{REFERÊNCIAS BIBLIOGRÁFICAS}

ALGRANTI, Leila Mezan. Artes de mesa: espaços, rituais e objetos em São Paulo Colonial (texto digitalizado). I Seminário Internacional Elementos Materiais da Cultura e Patrimônio, UFMG - Programa de Pós Graduação em História, Belo Horizonte, nov. 2011. 
ALGRANTI, Leila Mezan. Famílias e vida doméstica. In: SOUZA, Laura de Mello e. História da vida privada no Brasil, vol. 1 (org.). São Paulo: Companhia das Letras, 1997. p.83-154.

ARAÚJO, Maria Lucília Viveiros. Os caminhos da riqueza dos paulistanos na primeira metade do oitocentos. São Paulo: Hucitec/ Fapesp, 2006.

ARAÚJO, Maria Lucília Viveiros. Os interiores domésticos após a expansão da economia exportadora paulista. Anais do Museu Paulista, vol. 12, p.129-160, jan./dez. 2004.

BANDEIRA, Júlio; LAGO, Pedro Corrêa. Debret e o Brasil - Obra Completa. Rio de Janeiro: Capivara, 2013.

BANDEIRA, Júlio; WAGNER, Robert. Viagem pelo Brasil nas aquarelas de Thomas Ender. Rio de Janeiro: Kapa Editorial, 2000.

BORREGO, Maria Aparecida de Menezes. A teia mercantil: negócios e poderes em São Paulo colonial (1711-1765). São Paulo: Alameda/ Fapesp, 2010a.

BORREGO, Maria Aparecida de Menezes. Laços familiares e aspectos materiais da dinâmica mercantil na cidade de São Paulo (séculos XVIII e XIX). Anais do Museu Paulista, vol. 18, n. 1, p.11-41, jan./jun. $2010 \mathrm{~b}$.

BUENO, Beatriz Piccolotto Siqueira. Tecido urbano e mercado imobiliário em São Paulo: metodologia de estudo com base na décima urbana de 1809. Anais do Museu Paulista, vol. 13, n. 1, p.59-97, jan./jun. 2005.

CARVALHO, Vânia Carneiro de. Cultura material, espaço doméstico e musealização. Varia Historia, vol. 27, n. 46, p.443-469, jul./dez. 2011.

CARVALHO, Vânia Carneiro de. Gênero e artefato: o sistema doméstico na perspectiva da cultura material - São Paulo, 1870-1920. São Paulo: Edusp; Fapesp, 2008.

CARVALHO, Vânia Carneiro de. Gênero e cultura material: uma introdução bibliográfica. Anais do Museu Paulista, vol. 8/9, n. 9, p.293-324, 2003.

FLEXOR, Maria Helena Ochi. Mobiliário baiano. Brasília, DF: Iphan / Programa Monumenta, 2009.

FRANCO, Carlos. A sala de jantar nas casas de Lisboa: 1750-1825. In: SOUSA, Gonçalo Vasconcelos e (dir.). Matrizes da Investigação em Artes Decorativas II. Porto: UCE; CITAR, 2011. p.91-106. 
FREIRE, Fernanda Castro. Mobiliário. Móveis de assento e de repouso, vol. 1. Lisboa: Fundação Ricardo Espírito Santo, 2001.

FREIRE, Fernanda Castro. Mobiliário II, vol. 2. Móveis de conter, pousar e de aparato. Lisboa: Fundação Ricardo Espírito Santo, 2002.

GOODMAN, Dena. Furnishing discourses: readings of a writing desk in eighteenth-century France. In: BERG, Maxine; EGER, Elizabeth (eds.). Luxury in the eighteenth century: debates, desires and delectable goods. Houndmills, Balsingstoke, Hampshire: Palgrave, 2003. p.71-83.

GOODMAN, Dena; NORBERG, Kathryn (orgs.). Furnishing the eighteenth century: what furniture can tell us about European and American past. New York: Taylor Print, 2007.

HELLMAN, Mimi. Furniture, sociability, and the work of leisure in eighteenth-century France. Eighteenth-century Studies, vol. 32, n. 4, p.415-445, 1999.

KOUTSOUKOS, Sandra Sofia Machado. A casa e a "trastaria": história e iconografia de interiores de moradias da cidade do Rio de Janeiro na primeira metade do século XIX. Dissertação (Mestrado em Artes) - Instituto de Artes, Universidade Estadual de Campinas. Campinas, 1994.

LEMOS, Carlos Alberto. Casa Paulista: história das moradias anteriores ao ecletismo trazido pelo café. São Paulo: Edusp, 1999.

LIMA, Tânia Andrade. Chá e simpatia: uma estratégia de gênero no Rio de Janeiro oitocentista. Anais do Museu Paulista, vol. 5, n. 1, p.93-129, 1997.

LISBOA, Karen. A nova Atlântida de Spix e Martius: natureza e civilização na Viagem pelo Brasil (1817-1820). São Paulo: Hucitec, 1997.

LOUSADA, Maria Alexandre. A rua, a taberna e o salão: elementos para uma geografia histórica das sociabilidades lisboetas nos finais do Antigo Regime. In: VENTURA, Maria da Graça (coord.). Os espaços de sociabilidades na Ibero-América (sécs. XVI-XIX). Lisboa: Edições Colibri/ Instituto de Cultura Ibero-Americana, 2004. p.95-120.

LUNA, Francisco Vidal; KLEIN, Herbert. Evolução da sociedade e economia escravista de São Paulo, de 1750 a 1850. São Paulo: Edusp, 2005.

MADUREIRA, Nuno Luís. Cidade: espaço e quotidiano (Lisboa, 1740-1830). Lisboa: Livros Horizonte, 1992. 
MARCÍlIO, Maria Luiza. A cidade de São Paulo. Povoamento e população. 1750-1850. São Paulo: Pioneira/Edusp, 1974.

MARCÍLIO, Maria Luiza. Crescimento demográfico e evolução agrária paulista - 1700-1836. São Paulo: Hucitec/Edusp, 2000.

MARINS, Paulo César. A vida cotidiana dos paulistas: moradias, alimentação, indumentária. In: SETÚBAL, Alice (org.). Terra Paulista: histórias, arte, costumes, vol. 1. São Paulo: Imprensa Oficial; Cenpec, 2008. p.89-190.

MARINS, Paulo César Garcez. Através da rótula: sociedade e arquitetura urbana no Brasil, séculos XVII a XX, 2 vols. Tese (Doutorado em História Social) - Faculdade de Filosofia, Letras e Ciências Humanas, Universidade de São Paulo. São Paulo, 1999.

MARINS, Paulo César Garcez. O sobrado do Brigadeiro: domesticidade, sociabilidade e cultura material na residência urbana de uma fortuna do açúcar. I Seminário de História do Açúcar - Canaviais, Engenhos e Açúcar: história e cultura material, Museu Paulista, USP, p.1-9, Itu, 02 dez. 2005.

MATTOS, Renato de. Política e Negócios em São Paulo: da abertura dos portos à Independência (1808/1822). Tese (Doutorado em História Social) - Faculdade de Filosofia, Letras e Ciências Humanas, Universidade de São Paulo. São Paulo, 2015.

MEDICCI, Ana Paula. Administrando conflitos: o exercício do poder e os interesses mercantis na Capitania/Província de São Paulo. 1765-1824. Tese (Doutorado em História Social) - Faculdade de Filosofia, Letras e Ciências Humanas, Universidade de São Paulo. São Paulo, 2010.

MENESES, Ulpiano Toledo Bezerra de. A cultura material no estudo das sociedades antigas. Revista de História, n. 115, p.103-117, 1983.

MENESES, Ulpiano Toledo Bezerra de. Rumo a uma "História Visual". In: MARTINS, José de Souza; ECKERT, Cornelia; NOVAES, Sylvia Caiuby (orgs.). O imaginário e o poético nas Ciências Sociais. Bragança Paulista: EDUSC, 2005. p.33-56.

OLIVAL, Fernanda. Os lugares e espaços do privado nos grupos populares e intermédios. In: MONTEIRO, Nuno Gonçalo (ed.). História da vida privada em Portugal, vol. 2. Lisboa: Círculo de Leitores, 2011. p.244-275. 
PEREZ SAMPER, María de los Ángeles. Espacios e prácticas de sociabilidad en el siglo XVIII: tertulias, refrescos y cafés de Barcelona. Cuadernos de Historia Moderna, n. 26, p.11-55, 2001.

PÉREZ SAMPER, María de los Ángeles. La alimentación cotidiana en la España del siglo XVIII. In: GARCÍA HURTADO, Manuel-Reyes (coord.). La vida cotidiana en la España del siglo XVIII. Madri: Sílex, 2009. p.11-55. PINTO, Pedro Costa. O móvel de assento português do século XVIII. Lisboa: Medialivros, 2005.

RAMOS PALENCIA, Fernando. Pautas de consumo y mercado en Castilla 1750-1850. Economía familiar en Palencia al final del Antiguo Régimen. Madri: Sílex, 2010.

ROCHE, Daniel. O Povo de Paris: ensaio sobre a cultura popular no século XVIII. São Paulo: Edusp, 2004.

RODRIGUES, José Wasth. Descrições de mobiliário. São Paulo: Museu Paulista, 1948.

SARGENTSON, Carolyn. Inside the interior: furniture and its inner spaces in eighteenth-century France. In: ANSLEY, Jeremy; GRANT, Charlotte (eds.). Imagined interiors: representing the domestic interior since the Renaissance. London: New York: V \& A Publications, 2006. p.130-131. SELA, Eneida Maria Mercadante. Desvendando figurinhas: um olhar histórico para as aquarelas de Guilhobel. Dissertação (Mestrado em História) - Instituto de Filosofia, Letra e Ciências Humanas, Universidade Estadual de Campinas. Campinas, 2001.

STYLES, John. Lodging at the Old Bailey: lodgings and their furnishing in eighteenth-century London. In: STYLES, John; VICKERY, Amanda (orgs.). Gender, taste and material culture in Britain and North America, 1700-1830. New Haven; London: Yale Center of British Art: Paul Mellon Centre for Studies of British Art, 2006. p.61-80.

SUANO, Marlene. Alfaias, apetrechos, tarecos, trecos: os móveis. In: MENESES, Ulpiano Toledo Bezerra de (org.). Como explorar um museu histórico. São Paulo: Museu Paulista/USP, 1992. p.15-18.

TOLEDO, Benedito Lima de. O Triângulo e a configuração de suas ruas e largos. In: Cadernos de Fotografia Brasileira - São Paulo: 450 anos. Rio de Janeiro: Instituto Moreira Salles, 2004. p.360-380. 
TOLEDO, Benedito Lima de. São Paulo: três cidades em um século. São Paulo: Cosac Naify; Duas Cidades, 2007.

TORRÃO FILHO, Amílcar. A arquitetura da alteridade. A cidade luso-brasileira na literatura de viagem (1783-1845). São Paulo: Hucitec; Fapesp, 2010.

VALENÇA, César. A sala de jantar na segunda metade do século XIX. Braga: Universidade do Minho; Museu Nogueira da Silva, 2002 (Catálogo de exposição).

VICKERY, Amanda. Behind Closed Doors: At Home in Georgian England. New Haven, London: Yale University Press, 2009. 